\title{
GLOBALIZAÇÃO E REFORMAS LIBERALIZANTES: CONTRADIÇÕES NA REESTRUTURAÇÃO DO SETOR ELÉTRICO BRASILEIRO NOS ANOS 1990
}

\author{
Alessandro André Leme
}

\begin{abstract}
RESUMO
O artigo pretende lançar algumas questões para um debate crítico sobre as reformas do setor elétrico brasileiro na década de 1990. Assim, relaciona fatores exógenos e endógenos, ligados metodologicamente por uma abordagem histórico-estrutural que vincula o processo de industrialização do Brasil à dinâmica econômica internacional. Dessa forma, as reformas neoliberais da década de 1990 são percebidas no contexto das liberalizações promovidas em virtude do processo de globalização, em que a dinâmica do capitalismo - vinculada à expansão do capital financeiro - levou à redução dos estados nacionais. Nesse sentido, o setor elétrico brasileiro foi exemplar, pois o seu processo de privatização, planejado levando em consideração apenas questões econômico-financeiras, relegou a segundo plano questões de atendimento à população, apresentando problemas para a cidadania e mesmo, posteriormente, revertendo-se em dificuldades de abastecimento.
\end{abstract}

PALAVRAS-CHAVE: globalização; neoliberalismo; reformas do Estado; mercado; reestruturação do setor elétrico; privatização.

\section{INTRODUÇÃO}

Mesmo admitindo-se que exista uma espécie de economia-mundo desde o século XVI, é inegável que os processos de globalização intensificaram-se muito nas últimas décadas. Por mais que essa espécie de economia-mundo possa ser datada, por mais que de maneira embrionária, há vários anos, em nenhum momento da história ela cresceu e intensificou-se da forma apresentada a partir do período posterior à II Guerra Mundial e incisivamente nos últimos 20 anos em todo o globo terrestre.

Muitos são os traços e as evidências que podemos enumerar, sobretudo nas últimas duas décadas, sobre esta nova configuração da economia em esfera global e também para outros conjuntos de relações que perpassam o cultural, o político e até o espiritual. Um dos traços marcantes, por exemplo, "é a deslocação da produção mundial para a Ásia consolidando-se esta como uma das grandes regiões do sistema mundial”1 (SANTOS,

\footnotetext{
${ }^{1}$ Um dos principais fatores para este deslocamento são as condições objetivas de alto teor tecnológico e científico da produção.
}

1997). Como toda região produtora, a Ásia também é constituída por um centro (Japão), por uma região intermediária, ou semiperiferia (Coréia do Sul, Taiwan, Hong Kong e Cingapura), e por uma periferia (os demais países da Ásia). Outro traço marcante dessa nova configuração global da economia é o processo de primazia total das empresas multinacionais como agentes do "mercado global”.

A globalização, como conceito sociológico ou categoria utilizada pelas Ciências Sociais para entendimento dos novos processos e formas de organização das relações sociais em esfera mundial, é muito recente, podendo ser datada nos anos 1980 e 1990. Já como prática, evidencia as transformações e metamorfoses intensas no período posterior à Guerra Fria² .

O processo de globalização, como o próprio nome sugere, refere-se a acontecimentos e efei-

\footnotetext{
2 Isso não quer dizer que a globalização como um processo histórico-estrutural passou a existir apenas após a II Guerra Mundial. Na verdade, esse processo tem sido um fator prepem querante em todo o século XX, porém alguns marcos merecem destaque, entre os quais o fim da Guerra Fria, com a dissolução do bloco soviético e a intensificação e extensão do desenvolvimento capitalista.
} 
tos globais ou mundiais que se expressam por meio de representações simbólicas, de fabulações, de processos tecnológicos da informação, da integração de mercados (embora, em muitos casos, desigual e combinada (SANTOS, 1998) ou dos fluxos econômicos.

Explorando um pouco mais as questões referentes aos desenvolvimentos tecnológicos, Castells (1999) afirma que esse processo de globalização, baseado em um paradigma econômico-tecnológico da informação, marca simultaneamente um novo formato da organização social e também requer novas práticas sociais. Nesse sentido, os estados passam a organizar-se a partir do "Estado-rede"3, ou seja, por uma redefinição dos padrões de solidariedade e de difusão do trabalho segundo um padrão complexo de redes interligadas ${ }^{4}$. Com isso, o capital funciona globalmente como uma unidade em tempo real e é percebido, investido e acumulado principalmente na esfera da circulação (capital financeiro), o que passa a exigir novas formas de organização do Estado (idem, p. 499).

Em esfera nacional, a globalização também apresenta manifestações diversas, nas suas representações simbólicas, econômicas, políticas e culturais, como nas mudanças que impõe aos arranjos institucionais do Estado.

É justamente a partir dos limites imposto à autonomia dos estados nacionais por meio dos novos arranjos e desafios representados pela globalização, somados aos problemas e/ou fundamentados em uma crise endógena dos estados, que Bresser-Pereira, Wilheim e Sola (1999) evidenciaram que a reforma do Estado tornou-se tema

3 O Estado-rede caracteriza-se por uma redefinição do Estado-nação, principalmente porque compartilha a autoridade, ou seja, redefine a capacidade institucional de impor uma decisão via novas instituições, por um lado e, por outro, pela extinção de um centro e pela presença dos “nós de interconexão”. Com isso, gera uma adequação maior para processar a complexidade crescente de relações entre o global, o nacional e o local, a economia, a sociedade e a política, na era da informação (CASTELLS, 1999, p. 164).

4 A noção de “rede” para Castells (1999) é definida a partir de um conjunto de nós interconectados, em que, por meio de redes globalizadas, os estados têm apresentado que a distância (ou intensidade e freqüência da interação) entre dois pontos (ou posições sociais) é menor (ou mais freqüente, ou mais intensa) se ambos os pontos forem nós de uma rede do que se não pertencerem à mesma rede (idem, p. 498). central nos anos 1990. Primeiramente porque também há, segundo os autores, fortes indícios de transformações da sociedade, o que, por sua vez, começou a exigir novas formas de atuação do Estado, seja na sua capacidade de articulação com o poder Legislativo, seja principalmente na sua capacidade de dar respostas às novas demandas sociais (capacidade de governo). Por outro lado, a realização de reformas ou ajustes estruturais continua na agenda, como um elemento central para dar conta dos elementos de crises endógenos aos países.

Com repercussões locais distintas, realizamse reformas institucionais que compreendem a privatização, a "desestatização" de empresas, a desregulamentação da economia, a mudança da legislação trabalhista e a abertura dos mercados. Todos esses fenômenos estão subjacentes à dinâmica da globalização.

Por outro lado, as ocorrências exógenas têm sua respectiva relevância para efetivação de reformas nas esferas locais/nacionais, pois:

a) incorporam e implementam as políticas econômicas de inspiração dos programas de estabilização do Fundo Monetário Internacional (FMI), cujo fim prioritário são os países acometidos por situações financeiras críticas na intenção de diminuição do aparelho estatal;

b) estão também sob a inspiração do Banco Mundial, que exige uma adequação (via relatório) das políticas nacionais na concessão de empréstimos que os países em desenvolvimento venham a realizar e

c) são adotadas pela pressão de empresas transnacionais que de maneira oligopolista articulam-se para que a expansão estatal sofra obstáculo nos setores rentáveis da economia (FARIA NETO, 1994).

Obviamente, tais acontecimentos, como já assinalavam Cardoso e Faleto (1970), são movidas pela atuação de forças sociais internas de cada país ou de grupos de interesses que visam a ascender por meio de inserção nas novas áreas de investimentos decorrentes da privatização.

Ou seja, o processo de privatização seria fortemente influenciado tanto por atores exógenos quanto endógenos aos países, de que fazem parte macro-atores formuladores e implementadores de 
novos modelos de gestão dos setores infra-estruturais e de novos arranjos institucionais para regularem as transformações ocorridas.

Nesse sentido, as privatizações assumiram uma certa centralidade nas orientações político-econômicas reinantes no final do século XX, fundamentadas no discurso de eficiência da gestão privada nos negócios. Ressurgiu com isso o discurso centrado na possibilidade de retomada do desenvolvimento executado pelos recursos do setor privado em diversos setores da economia, antes assentados nos investimentos estatais.

Uma das seqüelas dessas ocorrências pode ser o enfraquecimento do Estado democrático de Direito (que vemos como contraposição ao "Estado mínimo" exigido pelo Consenso de Washington). A crítica ao aparelho estatal na forma de gerir setores fundamentais para o desenvolvimento do país, tais como da energia e das telecomunicações, configura-se como uma das formas discursivas e práticas para desmontá-los.

As privatizações, em particular as ocorridas no setor elétrico, corroboram com a consolidação da lógica de "Estado mínimo", em que o mercado adquire centralidade e hegemonia, sendo instrumento capaz de alocar com eficiência os recursos e distribuir com eqüidade os benefícios. Tal concepção beneficia a esfera privada em detrimento da esfera pública para o provimento dos serviços públicos, reservando nesse novo rearranjo o papel de mediador e regulador ao Estado.

A crítica à "pouca” eficiência dos monopólios estatais não leva em consideração que, historicamente, a gestão dessas empresas foi sacrificada em grande parte pela contenção e subsídio dos preços públicos em função de uma equivocada política de combate à inflação aliada à política de exportação, o que acabou refletindo diretamente no desequilíbrio do próprio orçamento do governo e também na desestruturação de muitas das empresas sob controle estatal (BATISTA, 1994).

A indústria da eletricidade é um dos segmentos visados pelos capitais para privatização. Historicamente, o setor energético, no Brasil, apresentou uma estrutura vertical, que consistiu em um parque gerador em uma ponta, a transmissão no meio e, na outra ponta, a distribuição. Porém, essa estrutura tem mudado sob dois aspectos: as tendências para 1) um modelo de integração horizontal e 2) uma estrutura privada, pretensamente com livre concorrência no mercado.

As reformas do setor elétrico em muitos dos países centrais, em grande parte, optaram pela manutenção da propriedade estatal sobre tal indústria, o que não excluiu do debate interno a construção e a implementação de políticas com alguns níveis de concorrência na geração de eletricidade (autoprodução, cogeração, produção independente), ou seja, uma tentativa de ampliação e viabilização de uma participação maior do capital privado em investimentos setoriais (ROSA, TOLMASQUIM \& PIRES, 1998).

Dos preceitos neoliberais veiculados pela globalização no concernente à função do Estado e as inúmeras reformas ocorridas - aqui destacamos as implementadas no setor de energia elétrica -, devem-se separar as benesses anunciadas daquilo que realmente ocorreu e/ou vem ocorrendo. Um outro fator que se insere nesta discussão é a disjunção entre eficiência e eqüidade ou, dito de outra forma, entre acumulação capitalista e inclusão social. Toda essa discussão é motivada pelo embate teórico e prático dentro da economia e da política entre os defensores do livre mercado e os keynesianos e/ou desenvolvimentistas que incluíam políticas nacionais de desenvolvimento, industrialização e "progresso" social.

O caráter estruturante da ação estatal posterior a 1945 foi indispensável para o crescimento capitalista. Promoveu-se o Estado de Bem-estar Social ou o Estado desenvolvimentista; regraramse as condições de trabalho; regulou-se a articulação do sistema financeiro e da concorrência intercapitalista - todas essas medidas sob o padrão intervencionista keynesiano (TAVARES, 1972).

A partir de 1973 iniciou-se um crescente processo de estagnação com inflação e sucessivas ondas de especulação contra o dólar (tendo como contrapartida as moedas européias), ocorrendo uma deterioração da capacidade de regulação monetária e financeira, inclusive dos Estados Unidos, engendrando-se, com isso, um quadro referencial para a industrialização, o consumo e o financiamento traçado para o período posterior à II Guerra Mundial (MACIEL, 1997).

A desestruturação global do sistema financeiro e produtivo, concomitantemente com o acirramento do processo de globalização, criou novos ordenamentos financeiros, produtivos e culturais, 
afetando de maneira desigual os países do Sul e os do Norte.

Nesse processo, dois movimentos consolidaram-se: as transações vultosíssimas que abrangeriam as fusões, as compras-vendas, os jointventures e outras combinações que resultam em novas formas de concentração do capital e a aceleração do ritmo do progresso técnico engendrado pela nova realidade oligopolista do capitalismo, em sentido político, social e econômico, que por sua vez traria conseqüências deletérias para o espaço social.

Mediante tal panorama, a privatização acena num primeiro instante para uma mudança na relação entre o Estado e a forma de condução da economia capitalista contemporânea, ocasionando, com isso, diversas possibilidades de inserção do capital privado em atividades produtivas diretas ou em serviços de utilidade pública.

Assim, destacam-se três modalidades de privatização:

a) desestatização das empresas públicas por meio da venda total ou parcial de ativos de propriedade pública direta ou indireta;

b) desregulamentação dos mercados das empresas públicas por intermédio de medidas que buscam expandir a competição e

c) contracting out e franchising, como tipos representativos de transferência da administração e da operação de atividades para o setor privado sem a renúncia ao controle estatal, de variada expressão (MACIEL, 1997).

Segundo Maciel, a privatização não decorreria da necessidade de saneamento das finanças públicas e de choque de eficiência econômica sobre a estrutura vigente. A abertura à concorrência, implicando a privatização ou não, é um movimento de readequação de espaços de valorização para gigantescas massas de capital financeiro. Porém, não foi exatamente esse movimento que se verificou no decorrer da década de 1990, principalmente no setor elétrico, que talvez seja o que mais problemas apresentou em decorrência das reformas nele realizadas.

Do ponto de vista teórico, as privatizações apresentaram como ponto central o fator econômico, ou seja, a desregulamentação e a liberalização aumentariam as condições competitivas do mer- cado, as quais garantiriam, por sua vez, a alocação eficiente de recursos.

Porém, uma avaliação mais precisa a respeito das formas de gestão (pública ou privada) merecem algumas pem querações. Primeiramente, os ditos "problemas de agências" não são restritos a empresas estatais, podendo ocorrer também em empresas privadas. Em segundo lugar, passados praticamente dez anos de reformas privatizantes no país, ficou evidente que a competição "pura" de mercado não é condição necessária e suficiente para engendrar por si só a diminuição das desigualdades nos serviços prestados e por sua vez uma alocação mais eficiente dos serviços.

O consultor do Banco Mundial Rafael Moscote, no seminário "Setor elétrico, o novo marco regulamentar”, realizado em São Paulo em setembro de 1996, apresentou qual seria o modelo ideal a ser seguido para a reestruturação do setor elétrico, a saber: o primeiro momento é o trabalho de idealizar a estrutura do novo sistema, fixar sua regulamentação, decidir acerca da forma de propriedade e estabelecer uma legislação adequada, respeitando as particularidades de cada país. Feito isso, passa-se ao segundo momento que consiste na caracterização ou execução do planejado que envolve a legislação, a regulamentação, a implantação da nova estrutura e a mudança de propriedade (de estatal para privado) (idem, p. 27).

Mediante a exposição do consultor do Banco Mundial e da própria percepção dos participantes do seminário, o processo de privatização brasileiro estava destoando da orientação do referido Banco, afinal, no Brasil haviam acontecido de forma simultânea a privatização, a nova legislação e a regulamentação do setor (ibidem).

Para maior democratização no novo modelo proposto para o setor elétrico, alguns cuidados deveriam ser tomados segundo Maciel: a garantia universal à energia elétrica por meio das políticas setoriais; a garantia de foros de representação dos usuários tradicionais e dos novos atores sociais; a garantia de informação ao público sobre temas de discussão; o estabelecimento de instâncias de recorrência, como uma forma ágil de solucionar possíveis conflitos; a supervisão do desempenho e das ações das empresas públicas federais e estaduais, empresas privadas, co-geradores, produtores independentes e outros atores e a implantação de políticas tarifárias dentre outras medidas (idem, p. 28). 
Com relação à nova política tarifária, algumas considerações devem ser feitas. Primeiramente, é necessário considerar a Lei n. 8 987, de 1995, que afirma que a tarifa resultaria do processo de licitação em que seria levado em conta o preço final da empresa. Uma vez o preço fixado pelos preceitos legais, será que as concessionárias sociabilizarão seus ganhos com os consumidores casos fiquem acima do esperado? No caso da Light, como exemplo histórico, as tarifas foram mantidas fixas por sete anos, engendrando benefícios unicamente aos compradores, que usufruíram de todos os ganhos de eficiência (ELETROPAULO, 1997).

Refletir sobre o setor energético brasileiro implica compreendê-lo historicamente para, a partir daí, evidenciarem alguns fatos importantes e cruciais para sua reestruturação. O setor elétrico brasileiro foi marcado por uma ausência de decisões efetivas capazes de equacionar as distorções ocorridas, em boa parte devido à falta de uma concepção integrada do setor energético em termos de formulação de políticas públicas e definição de prioridades.

Outro fator presente na questão energética na atualidade é a preservação ambiental, ou seja, a obtenção de energia com a menor exploração dos recursos naturais. Melhorar a eficiência na transformação (produção e consumo final), no transporte e na distribuição de energia elétrica juntamente com as proposições de sua universalização e de práticas tarifárias mais justas socialmente são apenas algumas das questões postas para a reflexão e para a crítica, passados praticamente dez anos de reformas no setor.

Com isso, é necessário verificar quais influências político-econômicas o país sofreu; em que contexto histórico-global ocorreram os fenômenos ligados à reestruturação do setor elétrico e sob quais dimensões geopolíticas e quais foram os atores pró-ativos nesse processo.

A compreensão das diversas políticas e dos inúmeros arranjos político-institucionais para o setor hidroelétrico brasileiro também são relevantes, seja por possibilitarem e redefinirem as funções do Estado para o setor, seja pela nova forma de regulação e normatização proposta e implementado para ele.

Refletir sobre a reestruturação do setor elétrico brasileiro extrapola em sua essência o domínio de um aspecto presente nas reformas do Estado brasileiro, ao tratar-se de um setor que em si é portador e definidor de todo um estilo de vida predominante na modernidade, ou seja, as relações cotidianas do homem com o próprio homem e do homem com a natureza em grande parte são intermediadas pela eletricidade, seja pela configuração urbano-industrial, seja pela própria extensão da cidadania a um conjunto de direitos que permeiam o estilo de vida decorrente da utilização e incorporação da energia elétrica para a vida cotidiana das pessoas.

\section{AECONOMIABRASILEIRANO SÉCULO XX EM PERSPECTIVA}

Entre 1907 e 1913, as condições da acumulação industrial já permitiam antecipar a liderança da indústria paulista no processo de industrialização. Passados os anos da I Guerra Mundial, a segunda valorização do café e a geada de 1918, houve a reposição das condições da acumulação cafeeira, que se reforçou com a política de defesa permanente do seu valor em 1922 e, ainda mais, a partir de 1924, com o Instituto Paulista de Defesa Permanente do Café.

O final dos anos 1910 e o início da década de 1920 marcaram, portanto, o início de um ciclo de expansão da economia cafeeira paulista, que trouxe à tona a possibilidade de uma diversificação crescente da economia no aspecto urbano-industrial, além de dar algum fôlego ao mundo agrário. A acumulação industrial definiu a primazia paulista, não apenas pelo seu maior crescimento mas, sobretudo, pela significativa transformação qualitativa da estrutura produtiva. A agricultura do estado, já diversificada no começo do século XX, assistia ao início de um processo que viabilizava sua rápida reestruturação após a crise dos anos 1930.

Em São Paulo ${ }^{5}$ criaram-se as condições para

5 Até 1879 a Província de São Paulo viu criarem-se 100 municípios e nos últimos 20 anos do século XIX criaramse mais 61, entrando São Paulo no século XX com 161 municípios. Na primeira década do século XX, marcada pela crise cafeeira, nenhum novo município foi criado, mas nos anos 1910 a retomada da expansão cafeeira levou à criação de mais 31 municípios e, na década seguinte, quando o governo estadual assumiu diretamente a política de sustentação do café, houve uma febre expansionista na frente pioneira, em que mais de 53 municípios foram criados. Assim, São Paulo entrou na crise de 1929 com uma rede urbana constituída por 245 municípios - quase a metade do número atual. 
uma acumulação capitalista diversificada: não apenas o café, mas também estradas de ferro, bancos, indústrias de diversos setores, comércio e a eletricidade, além de outras. O capital cafeeiro desdobrou-se em múltiplas faces. Entre 1886 e 1913, com exceção dos anos de crise do final do século XIX e o início do século XX, deu-se o nascimento da indústria paulista. Mas foi justamente durante a década de 20 que o crescimento industrial assegurou a liderança nacional do estado. Em 1907, São Paulo participava com 16\% na produção industrial do país, valor que passou para 31\% em 1919 e 41\% em 1939.

Diferentemente do café escravista, cuja herança foi a paisagem das "cidades mortas" do Vale do Paraíba, a nova expansão cafeeira do começo do século XX impulsionou a vida urbana nos centros do Leste, sobretudo na capital paulista. Nesse processo foram definidas regiões e foi organizada uma primeira hierarquia no sistema estadual de cidades.

O complexo cafeeiro, ao desenvolver-se, deu origem à estrutura básica da rede urbana paulista, necessária tanto para sustentar a produção do café como para permitir o seu escoamento e comercialização. A rede urbana criada pelo e para o café assentou-se no desenho viário das ferrovias, em que se distribuíam núcleos urbanos que davam apoio principalmente às necessidades de consumo dos colonos e dos pequenos produtores agrícolas e às necessidades de armazenagem, operação e transporte da produção cafeeira. Em resposta a estas demandas estruturou-se, principalmente nas regiões de Campinas e Ribeirão Preto, uma rede urbana relativamente densa e ramificada, pontuada por centros maiores, que centralizavam o comércio e a prestação de serviços em relação a uma certa área, fazendo a mediação entre a capital e o interior do estado.

Assim, a indústria apropriou-se da rede urbana produzida pela e para a economia cafeeira e reforçou a polarização de certos núcleos originados do próprio complexo cafeeiro.

Desde o final do século XIX, a sociedade brasileira vinha passando por longos e complexos processos históricos que engendraram transformações sócio-econômicas e conseqüentemente estabeleceu um novo padrão de organização social e um novo estilo de vida para a sociedade como um todo e para o cotidiano das pessoas em particular.
Parte dessas transformações sócio-econômicas referem-se à abolição da escravatura, a economia cafeeira, a imigração, o nascimento da indústria, o crescimento das cidades, as ferrovias, o estabelecimento da energia elétrica assentada na base hidráulica.

Essas mudanças geraram novos atores, novas necessidades e novas formas de organização tanto do Estado como da sociedade civil como um todo. Foi nesse contexto de grandes transformações que a energia elétrica gradativamente começou a adentrar a sociedade como um dos fatores essenciais para a adoção de um novo padrão de organização social e industrial. A energia surgiu como a possibilidade histórica para o desenvolvimento urbano-industrial do país.

Com a revolução de 1930, ocorreu uma centralização do Estado para o estímulo ao desenvolvimento nacional. Com isso, o papel do Estado na economia passou a ser mais essencial do que nunca, seja no que se refere ao câmbio e à alfândega, seja no que se refere à reorientação do processo industrial assumido pelo país. O censo de 1940 já expressava um relativo desenvolvimento industrial do país, com uma leve vantagem para o desenvolvimento industrial paulista. Esse período 1930-1945 - foi denominado de "industrialização restringida”6 por Tavares (1986).

Como se pode perceber, embora praticamente todo o primeiro qüinqüênio do século $\mathrm{XX}$ foi marcado por uma estrutura social e econômica assentada em sua maioria no ambiente rural, já havia indícios de um novo modo de organização centrado na industrialização e urbanização do país, especialmente da cidade de São Paulo. Mediante os processos supra-indicados, instaurou-se a energia elétrica no país, não só como sinônimo de

6 Essa expressão foi utilizada por Maria da Conceição Tavares (1983) para definir o período de industrialização incipiente no Brasil que data de 1930 a aproximadamente 1945, em que se intensifica o processo de industrialização em um quadro de organização dos padrões sociais já com características mais urbano-industriais. Além disso, e mais especificamente, pode-se com ele entender o processo por meio do qual a dinâmica da acumulação assenta-se na expansão industrial, mas esta encontra-se restringida, pois as fragilidades das bases técnicas e financeiras não permitiam, na época, que se implantasse, de uma só vez, um segmento de bens de produção capaz de assegurar a autodeterminação do processo de acumulação. 
desenvolvimento e modernidade, mas também como arranjadora de uma nova estrutura organizacional adotado pela Estado e incorporado pela população aos seus estilos de vida.

A partir do Plano de Metas de Juscelino Kubitschek - com a promessa de "cinqüenta anos de progresso em cinco de governo" -, foram propostas em 1956 algumas diretrizes para o desenvolvimento industrial nacional, em que, de fato, começou a solidificar-se o tão esperado e desejado desenvolvimento industrial brasileiro, particularmente o paulista, que em 1955 já detinha 52\% da participação total da indústria nacional. $\mathrm{O}$ caminho a seguir contemplava soluções pragmáticas que contavam com a participação da iniciativa privada - nacional e estrangeira - e de empresas sob o controle do Estado, na tentativa de evitar posições ideológicas extremadas.

Durante o governo do presidente Kubitschek (1956-1960), instituiu-se um Conselho de Desenvolvimento, que tinha a sua secretaria no Banco Nacional de Desenvolvimento Econômico (BNDE), posteriormente denominado de Bndes (Banco Nacional de Desenvolvimento Econômico e Social). O setor energético absorveu quase a metade do orçamento global do Plano de Metas e a energia elétrica, cerca de metade do valor conseguido por todo o setor energético.

Isso salienta o quanto no processo de execução do Plano a energia elétrica teve prioridade. A criação do Ministério das Minas e Energia ao final do governo de Kubitschek só reforçou (MME) a influência e a importância desse setor para o desenvolvimento industrial do Brasil.

A implantação das fábricas de automóveis, ainda durante a década de 1950, foi um marco na industrialização do país; associada à construção e à modernização das estradas de rodagem, deu origem ao intensivo aumento da demanda de derivados de petróleo.

Por outro lado, era geral a conviç̧ão entre políticos e pesquisadores de que as condições do suprimento de energia já estavam deficitárias e, caso nada fosse realizado, tenderiam a agravarse. Nesse período já estava em gestação o projeto de Furnas, cujo aproveitamento do potencial do Rio Grande teria fundamental importância no suprimento e na interligação dos sistemas da região Sudeste. Furnas acrescentaria um milhão de kW a um sistema de três milhões de quilowatts. Algu- mas objeções ficaram conhecidas, dentre elas as desvantagens das grandes usinas com seus reservatórios (Peixotos, Três Marias e Furnas) em face de usinas de menor porte e os malefícios decorrentes do deslocamento de populações e de suas respectivas atividades agrícolas produtivas.

Em atitude pragmática e considerando indispensável uma grande solução para a crise de energia da região Sudeste - nos moldes da que havia sido adotada para o Nordeste, com a criação da Companhia Hidrelétrica do São Francisco (Chesf), em 1945 -, o governo de Kubitschek aprovou a fundação da Central Elétrica de Furnas, em 1957, sem solicitar autorização do Congresso Nacional.

Em Minas Gerais, os projetos técnicos de Furnas e Três Marias tiveram início ao mesmo tempo em que o seu ex-Governador, Juscelino Kubitschek, lançava-se candidato a Presidente da República. Ao assumir a Presidência, o projeto de Furnas já estava em condições de ser lançado. A principal dificuldade era definir a estrutura empresarial. Tratava-se então de um empreendimento do governo federal, cujo objetivo era o de suprir com energia elétrica outros estados da federação. Minas Gerais, por sua vez, dispunha do seu próprio projeto para o seu referido espaço geográfico e político com a execução da usina hidroelétrica de Três Marias.

São Paulo, por sua vez, também tinha seu projeto em Urubupungá. Cogitava-se interligar sistemas até então isolados e, por fim, suprir concessionários de capital estrangeiro que distribuíam a maior parte da eletricidade de toda a região de influência de Furnas, quais sejam: a Light, que nesse período ainda detinha mais de metade do mercado, e três subsidiárias da American \& Foreign Power Co. (Amforp).

A Eletrobrás (Centrais Elétricas Brasileiras), cujo projeto estava no Congresso Nacional havia sete anos, só teria sua criação autorizada, com grandes simplificações, em 1961, já no governo Jânio Quadros. A ela incorporaram-se a Chesf e Furnas e para ela transferiram-se atribuições do BNDE referentes ao financiamento do setor elétrico e à gestão do Fundo Federal de Eletrificação.

A constituição da Eletrobrás processou-se de maneira bastante lenta. Dois temas eram cruciais: sua auto-suficiência econômico-financeira e a integração física do sistema elétrico, que ainda viria 
a demandar muito tempo para ser definida.

Por iniciativa da Companhia Energética de Minas Gerais (Cemig), depois transformada em empreendimento de amplitude regional, foi solicitado ao Fundo da Organização das Nações para a América Latina que realizasse um levantamento sobre os recursos hídricos da região Sudeste e seus respectivos potenciais para geração de energia elétrica.

Na avaliação do mercado potencial, procurouse fugir da simples extrapolação estatística do passado, buscando projeções da estrutura econômica futura e/ou de variáveis macro-econômicas, traduzindo-as, depois, em requisitos de energia elétrica.

A consolidação econômica dos serviços de eletricidade só se completaria, entretanto, no governo do Presidente Emílio Médici com a aprovação de um decreto de regulamentação geral do imposto único, do empréstimo compulsório e do Fundo Federal de Eletrificação, dentre outros de menor importância. As grandes beneficiárias desses recursos eram o grupo Light, que, em tese, deveria trazer recursos privados externos para a sua própria capitalização, e a Companhia Energética de São Paulo (CESP), controlada pelo estado mais rico da federação, São Paulo.

Visando a garantir a eficiente operação dos sistemas interligados das regiões Sudeste e Sul, institucionalizaram-se dois Comitês Coordenadores da Operação Interligada (CCOI), que vinham operando de maneira experimental e satisfatoriamente desde 1969 na região Sudeste, e desde 1971, na Região Sul. Os novos organismos designados GCOI (Grupo Coordenador para Operação Interligada) incorporavam representantes da Eletrobrás e de suas subsidiárias, bem como das concessionárias estaduais de cada região - as últimas em maioria. (Apenas bem mais tarde foram instituídas e depois ampliadas à coordenação do Nordeste e do Norte do país.)

Em uma análise perspicaz, Ianni assinala que o planejamento econômico no Brasil, de 1930 a 1970, contou com dois fatores importantes:

a) preponderância do projeto de desenvolvimento nacional nos anos 1930-1945, 19511954 e 1961-1964 e predomínio da estratégia de desenvolvimento dependente nos períodos 1946-1950, 1955-1960 e 19641970 e b) as políticas econômicas governamentais dos anos 1930-1970 comportaram-se de maneira a estimar, reduzir e/ou controlar os riscos políticos a que poderiam estar sujeitos os investimentos privados, de origem nacional ou multinacional (IANNI, 1986).

Independentemente da escolha pelo projeto de desenvolvimento nacional ou de desenvolvimento dependente, a questão energética, em particular a questão da hidroeletricidade, acabou ocupando expressiva relevância e centralidade na forma de pensar e fazer política no Estado brasileiro, tendo sempre em vista suas possibilidades de desenvolvimento e modernização do país.

\section{O SETOR ELÉTRICO EM PROL DA HI- DROELETRICIDADE NO BRASIL}

O Brasil, historicamente, constituiu seu setor elétrico com uma vocação hidroelétrica, dispondo de uma capacidade nominal instalada de 61312 MW. A predominância da hidroeletricidade no Brasil só encontra similar na Noruega que, por sua vez, apresenta uma potência instalada em cerca de aproximadamente $50 \%$ da capacidade instalada brasileira.

Segundo estudos da Eletrobrás, o Brasil ainda apresenta condições fluviais para, no mínimo, triplicar a sua capacidade de geração hidroelétrica, seja por meio de grandes projetos hídricos (GPHs), seja por pequenas centrais hidroelétricas (PCHs) (H2OPLANET, 2006).

A década de 1990, por sua vez, apresentou dois movimentos simultâneos, porém, não de mesma intensidade: o primeiro, e de maneira mais restrita, foram os novos investimentos no setor (como os que permitiram o término da Usina Hidroelétrica (UHE) de Porto Primavera, denominada recentemente UHE Engo Sérgio Motta, que contou com o esforço de parceria com o capital privado); o segundo, mais prepositivo e intenso, consistiu na deflagração de uma reforma cuja principal característica é a mudança na atuação do Estado no setor, passando de investidor para regulador.

Outro fator considerado de importância, ao lado das reformas realizadas no setor elétrico brasileiro, é a associação necessária, entre o consumo energético, a qualidade de vida e a sustentabilidade ambiental, todos essenciais para o estilo de vida na modernidade. 
No que se refere ao consumo energético, há grandes disparidades entre os países desenvolvidos e os países considerados em desenvolvimento, configurando um quadro mundial de desigualdades no que se refere à qualidade de vida (considerando o consumo de energia elétrica como um indicador de qualidade de vida).

Por outro lado, as desigualdades não são somente entre países, mas também há grandes desigualdades segundo as regiões e/ou classes sociais. Isso evidencia que há diferenças tanto na distribuição e na disponibilidade de recursos naturais pelas diversas regiões do país, como no desenvolvimento tecnológico, quanto, por fim, na maneira como a riqueza (renda) é distribuída.

No caso brasileiro, o atual disponibilidade energética, que envolve a produção de bens e serviços energéticos (iluminação, aquecimento, refrigeração e força motriz), e as condições de acesso da população a esses serviços e bens é extremamente desigual (BERMANN, 2002, p. 16).

Nesse sentido, deve ser encarado como um desafio a sustentabilidade energética brasileira, levando em conta os fatores sociais e ambientais, as condições por que a renda distribui-se de maneira desigual e concentrada pelo país. Somente a partir do momento em que percebermos essas disparidades é que poderemos refletir de maneira mais eficiente sobre as possíveis alterações a serem realizadas no setor elétrico de forma sinérgica com outros fatores essenciais a reprodução social dos indivíduos com qualidade/eqüidade e sustentabilidade ambiental e energética.

TABELA 1 - DESIGUALDADE DE RENDA NO BRASIL, SEGUNDO A PARTICIPAÇÃO DE CADA GRUPO DE RENDA NO RENDIMENTO TOTAL (1982-1999, EM \%)

\begin{tabular}{|l|c|c|c|c|c|c|c|}
\hline \multicolumn{1}{|c|}{ GRUPOS DE RENDA } & $\mathbf{1 9 8 1}$ & $\mathbf{1 9 8 6}$ & $\mathbf{1 9 9 0}$ & $\mathbf{1 9 9 3}$ & $\mathbf{1 9 9 5}$ & $\mathbf{1 9 9 8}$ & $\mathbf{1 9 9 9}$ \\
\hline $\mathbf{1 0 \%}$ mais pobres & 0,9 & 1,0 & 0,8 & 0,7 & 1,1 & 1,2 & 1,2 \\
\hline $\mathbf{2 0 \%}$ mais pobres & 2,9 & 3,1 & 2,4 & 2,7 & 3,3 & 3,5 & 3,6 \\
\hline $\mathbf{5 0 \%}$ mais pobres & 14,5 & 13,5 & 11,2 & 12,8 & 13,0 & 13,5 & 13,9 \\
\hline $10 \%$ mais ricos & 44,9 & 47,3 & 49,7 & 49,8 & 48,2 & 47,5 & 46,8 \\
\hline $\mathbf{5 \%}$ mais ricos & 31,9 & 33,9 & 35,5 & 36,6 & 34,6 & 34,0 & 33,4 \\
\hline $\mathbf{1} \%$ mais rico & 12,1 & 14,0 & 14,6 & 16,0 & 13,9 & 13,7 & 13,0 \\
\hline Índice de Gini & $\mathbf{0 , 5 6 4}$ & $\mathbf{0 , 5 8 4}$ & $\mathbf{0 , 6 2 0}$ & $\mathbf{0 , 6 0 3}$ & $\mathbf{0 , 5 9 2}$ & $\mathbf{0 , 5 8 4}$ & $\mathbf{0 , 5 7 6}$ \\
\hline
\end{tabular}

FONTE: Bermann (2002, p. 16).

NOTAS:

1. Considera-se o rendimento mensal de todas as pessoas de 10 anos ou mais, com rendimento.

2. O Índice de Gini varia de 0 (igualdade máxima) a 1 (desigualdade máxima).

Como evidenciado na tabela acima, o grau de desigualdade na distribuição de renda praticamente não se alterou nem a partir do Plano Real (1994) e nem com a própria estabilização da moeda nos últimos anos, o que evidencia que o ajuste fiscal e o controle inflacionário em si não contribuem diretamente e nem de maneira efetiva para a diminuição da desigualdade. Praticamente há uma equivalência da participação da renda entre os $50 \%$ mais pobres com os $1 \%$ mais ricos, demonstrando claramente a grande concentração de renda que existe no Brasil.
Nesse sentido as alterações realizadas no setor elétrico brasileiro em si também não poderão alterar de maneira significativa o acesso ao uso da energia, evidenciada aqui como um indicador de qualidade de vida.

\section{AS REFORMAS POLÍTICO-INSTITUCIO- NAIS REALIZADAS NO SETOR ELÉTRI- CO BRASILEIRO NA DÉCADA DE 1990}

O setor elétrico brasileiro apresentou historicamente uma estrutura vertical que consistiu em um parque gerador em uma ponta, a transmissão 
no meio e, na outra ponta, a distribuição, ou seja, uma estrutura hierarquizada com o Estado controlando todas as fases do processo (geração, transmissão e distribuição). Porém, com os novos arranjos político-institucionais para o setor elétrico, essa estrutura tem mudado para um modelo de integração horizontal, ou seja, ocorreu uma alteração na estrutura estatal hierarquizada para uma estrutura privada de livre concorrência no mercado. Essa estrutura horizontalizada com geradores independentes, distribuidores independentes e transmissão mista (porém, poucas linhas de transmissão foram privatizadas, sendo mantidas a maior parcela delas nas mãos do Estado).

A década de 1990 foi marcada por muitas reformas realizadas no Estado brasileiro, especialmente as ocorridas no setor elétrico. O processo de reestruturação do setor elétrico acirrou-se a partir de 1993 com a promulgação da Lei n. 8 6317. Em 1995, com a promulgação da Lei das Concessões n. 8987 e do Decreto n. 9 074, que regulamentaram o artigo 175 da Constituição Federal ${ }^{8}$, criaram-se condições legais para que os geradores e distribuidores de energia elétrica pudessem competir pelo suprimento dos grandes consumidores de energia elétrica.

Porém, a privatização começou a ser implementada antes que o Estado tivesse criado os mecanismos necessários para a nova regulação do setor. A Agência Nacional de Energia Elétrica (Aneel) foi criada somente em 6 de outubro de 1997, por meio da aprovação do Decreto n. 2335. A Aneel veio exercer a função de órgão regulador em nível federal, substituindo o Departamento Nacional de Energia Elétrica (Dnaee) e reordenando as áreas de negócios do setor em produção de

\footnotetext{
7 Essa lei eliminou o regime tarifário pelo custo de serviço, abrindo espaço para o processo de criação do Produtor Independente de Energia (PIE) e o estabelecimento de regras para fixação de níveis tarifários, além de estabelecer a obrigatoriedade de contratos de suprimento de energia (contendo quantidades e preços) (FERREIRA, 2000).

8 O artigo 175 incumbiu “ao Poder Público, na forma da lei, diretamente ou sob regime de concessão ou permissão, sempre por meio de licitação, a prestação de serviços públicos. - Parágrafo único. A lei disporá sobre: o regime das empresas concessionárias e permissionárias de serviços públicos, o caráter especial de seu contrato e de sua prorrogação, bem como as condições de caducidade, fiscalização e rescisão da concessão ou permissão; os direitos dos usuários; política tarifária; a obrigação de manter serviço adequado” (BRASIL, 1988).
}

energia (geração); transporte nas tensões mais altas (transmissão); transporte com o específico objetivo de atendimento a consumidores finais (distribuição) e vendas no varejo, com a função de medir e conquistar os consumidores finais (comercialização).

Em esfera estadual, também foram criadas agências reguladoras, outras 12 unidades da federação criaram suas agências de regulação (porém, vinculadas à Aneel) do setor elétrico para atender a especificidades da regulação estadual. Suas respectivas agências são: na região Norte, a Agência Estadual de Regulação e Controle dos Serviços Públicos (Arcon, do estado do Pará); na região Nordeste, a Agência Reguladora de Serviços Públicos Delegados do Estado do Ceará (ARCE), a Agência Reguladora de Serviços Públicos do Rio Grande do Norte (Arsep), a Agência Estadual de Regulação de Serviços Delegados de Pernambuco (ARPE), a Agência Reguladora de Serviços Concedidos do Estado de Sergipe (ASES) e a Agência de Regulação de Serviços de Energia, Transportes e Comunicações (Agerba, do estado da Bahia); na região Sudeste, a Agência de Regulação dos Serviços Públicos (Agersa, do estado do Espírito Santo), a Agência Reguladora de Energia e Saneamento Básico do Estado do Rio de Janeiro (Agenersa) e a Comissão de Serviços Públicos de Energia (CSPE, do estado de São Paulo); na região Centro-Oeste a Agência Estadual de Regulação de Serviços Públicos de Mato Grosso (AGER) e a Agência Goiana de Regulação, Controle e Fiscalização dos Serviços Públicos (AGR); por fim, na região Sul, a Agência de Regulação do Rio Grande do Sul (Agergs).

São tantas as atribuições, ao lado do aporte financeiro ao capital externo (via Bndes) para aquisição das concessionárias, que nos fazem suspeitar do uso indevido do termo "desregulamentação" para caracterizar o que parece ser, não a retirada estatal do setor elétrico, mas sua mudança na forma de atuação.

Por outro lado, esse processo de reestruturação do setor elétrico brasileiro, na sua realização, ainda contou com um ordenamento que consistiu na contratação por parte do Ministério de Minas e Energia (MME), em 1996, de um consórcio, liderado pela empresa Coopers \& Lybrand ${ }^{9}$ e pelas empresas Lathan \& Watkins (ligadas ao ramo de

9 Empresa com fortes interesses no gás da Bolívia. 
consultoria internacional) e pelas empresas nacionais Main e Engevix (ambas do ramo de engenharia, gerenciamento de projetos e obras), além de uma empresa de consultoria na área jurídica, a Ulhôa Canto, Rezende e Guerra, visando a colher sugestões para a montagem de um novo desenho para o mercado elétrico brasileiro e de uma nova aparência institucional, o que, a partir daí, convencionou-se chamar de "Projeto de Reestruturação do Setor Elétrico Brasileiro" (Reseb) (LONGO \& BREMANN, 2002).

Era esperado da consultoria que houvesse sugestões que partissem de uma adaptação dos ensinamentos e experiências das reformas ocorridas em outros países, mas considerando as especificidades do setor elétrico brasileiro (FERREIRA, 2000).

Dentre as especificidades do caso brasileiro, o Governo Federal advertiu as seguintes:

a) por ser federativo, o regime brasileiro torna indispensável a divisão dos poderes regulatórios entre o governo federal e os governos estaduais. Essa divisão traduz-se em uma delicada negociação política em uma circunstância em que as empresas elétricas controladas pelos governos estaduais já estão sendo privatizadas (ABRUCIO \& COSTA, 1999);

b) o sistema elétrico brasileiro é de base hidráulica, sendo necessária uma forte coordenação da operação na introdução do processo de concorrência na geração;

c) a rede de transmissão brasileira deveria buscar progressivamente interconectar-se em um sistema nacional;

d) dadas as significativas diferenças regionais e empresariais, alguns mecanismos de compensação regionais precisariam subsistir por um período significativo e

e) a existência de um grande número de empresas controladas por governos estaduais, muitas delas com significativos ativos de transporte e geração, exigiria a convivência de empresas privadas e estaduais no mercado elétrico brasileiro durante um período (REZENDE \& PAULA, 1997).

Não obstante essas especificidades, as principais sugestões da Coopers \& Lybrand e demais consultoras e aceitas pelo governo brasileiro foram: a) a criação de um mercado atacadista de eletricidade (MAE) ${ }^{10}$, recentemente substituído pelo mercado de energia brasileiro (MEB);

b) o estabelecimento de "contratos iniciais" para criar uma fase de transição para o mercado de energia elétrica competitivo;

c) o desmembramento dos ativos de transmissão e a criação de um Operador Independente do Sistema (OIS) para administrar o sistema interligado e

d) a organização das atividades financeiras e de planejamento neste novo cenário (FERREIRA, 2000).

No campo específico da geração, as recomendações também foram significativas no que tange à transparência e ao acesso livre ao mercado. Dentre o conjunto de recomendações, destacamse as seguintes:

a) a desverticalização da geração no que se refere aos ativos federais e estaduais por meio da criação de empresas separadas de geração, as denominadas "gencos”, para garantir que o acesso ao mercado de atacado seja livre e

b) a separação horizontal das duas maiores "gencos" federais, Furnas e Chesf, para a criação de duas novas empresas menores a partir de cada uma delas (LONGO \& BREMANN, 2002).

Desse modo, não nos parece que a consultora ateve-se plenamente à realidade brasileira, em que o mercado atacadista não incluirá, no médio prazo, novos produtos como os que obterão a energia por fontes térmicas (óleo, gás, carvão e nuclear como na Inglaterra). Outro equívoco relevante da consultoria foi ter desprezado em suas análises o controle de cheias, irrigação, abastecimento de água potável, navegação e desenvolvi-

\footnotetext{
10 O MAE exerce a função de intermediador de todas as transações de compra e venda de energia elétrica dos sistemas elétricos interligados. No Brasil houve a criação de quatro submercados spots, quais sejam: Norte, Nordeste, Sudeste e Sul-Centro-Oeste. Participam do MAE os geradores com capacidade igual ou superior a $50 \mathrm{MW}$, todos os varejistas com carga igual ou superior a $100 \mathrm{GWh}$ e todos os grandes consumidores com demandas acima de $10 \mathrm{MW}$ (TOLMASQUIM \& CAMPOS, 2002).
} 
mento regional integrado, questões que são vitais para a nova modelagem energética no Brasil (REZENDE \& PAULA, 1997; MEIRELES, 1999).

O novo modelo de regulação definido pelo governo federal dividiu o setor em quatro segmentos, cada qual com uma forma distinta de operacionalização e um agente envolvido. O seg- mento da geração foi aberto à concorrência privada; o segmento da transmissão permanece como monopólio gerido pelo Operador Nacional do Sistema Elétrico (NOS) ${ }^{11}$; o segmento da distribuição também continuaria como monopólio gerido por concessionárias e, por fim, o segmento da comercialização foi aberto à competição pelas comercializadoras.

FIGURA 1 - MODELO DE REGULAÇÃO DO SETOR DE ENERGIA ELÉTRICA

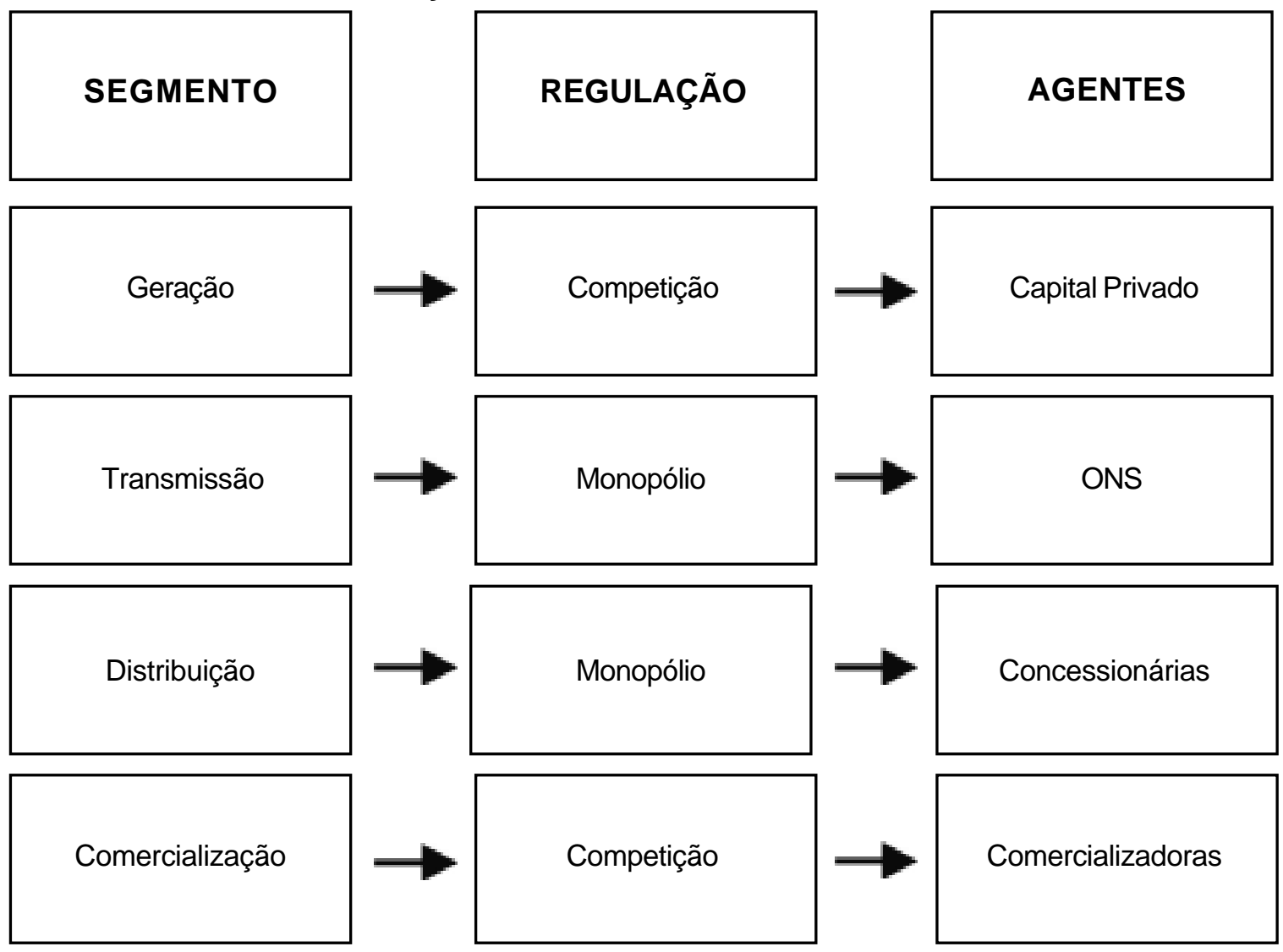

Fonte: Rezende e Paula (apud LEME, 2000).

Tendo em vista as possíveis contradições contidas entre a realidade do setor elétrico brasileiro e as propostas oriundas da consultora Coopers \& Lybrand, é mister supor que a reestruturação do setor elétrico merece um olhar crítico. Sob tal perspectiva, Biondi (1999), Petras (1999), Cano (2000) e Bermam (2002), dentre outros, demonstram que o processo de privatização não tem sido uma opção de política nacional planejada e discutida publicamente com toda sociedade civil na intenção de consolidar mecanismos democráticos na gestão do setor elétrico brasileiro.

Petras (1999) não vê com isenção o discurso oficial que exacerba a privatização como um ato econômico resultante da "racionalidade do mer-

11 O ONS é uma espécie de cooperativa que reúne geradores, transmissores, distribuidores, importadores, exportadores e associações de consumidores de energia elétrica. Ele é uma entidade de direito privado, sem fins lucrativos e que está estruturado sob a forma de associação civil; dele participam geradores, empresas de transmissão e de distribuição, consumidores livres, comercializadores, importadores e exportadores de eletricidade. Suas funções consistem na garantia da qualidade do suprimento elétrico na rede de transmissão; na garantia de que todos os agentes do setor elétrico tenham acesso aos serviços prestados pela rede de transmissão e no despacho das centrais cujo objetivo é a minimização do preço de energia no mercado atacadista (TOLMASQUIM \& CAMPOS, 2002). 
cado", que nos "redimirá" dos "equívocos estatizantes” do passado. Ao contrário, o crescimento das empresas públicas nas últimas décadas deu-se como uma resposta aos fracassos e crises do regime de "livre mercado"12 que aqui se pretendeu implantar outrora.

Esse processo tem sido unidirecional, respondendo menos aos interesses dos cidadãos e dos consumidores de energia do país do que à conveniência das empresas concessionárias - em sua grande maioria estrangeiras ${ }^{13}$ - que vem explorando, em sentido lato, o mercado nacional de energia. Tal situação corresponde a uma realidade heterônoma ${ }^{14}$ marcada pela disputa dos interesses das empresas transnacionais do setor.

Existe a necessidade de analisar-se a privatização em uma perspectiva histórico-estrutural ${ }^{15}$, a partir da qual é possível constatar a ocorrência de modificações na relação entre o Estado e o setor privado. Embora as características da

12 A noção de "livre mercado", desde Adam Smith até nossos dias, com as proposições neoliberais de Friedrich Hayek e Milton Friedman, é identificada como o espaço pelo qual ocorre a liberdade natural dos indivíduos. É o local extrapolítico sem a existência de coerção.

13 AES (Estados Unidos), Houston (Estados Unidos), CEA (Estados Unidos), Enron (Estados Unidos), DukeEnergy (Estados Unidos), Tractebel (Bélgica), EDF (Francesa), EDP (Portuguesa), Endesa (Espanha), Iberdrola (Espanha), Endesa (Chile) e Chilectra (Chile) são apenas algumas das empresas transnacionais que participam da distribuição e geração de energia elétrica brasileira.

14 Esse processo de heteronomia do poder político nacional já foi amplamente debatido por Fernandes (1981). Para o autor, tal processo tem historicamente criado situações em que os rumos nacionais são fortemente influenciados por interesses exógenos e tem-se atrelado à rede de relações político-econômico tradicionais do Estado brasileiro, formando um compósito deletério ao pleno desenvolvimento social da nação.

15 O conceito de "processo histórico-estrutural” parecenos particularmente interessante por permitir, no âmbito metodológico, a necessária fusão entre estrutura e história na análise social. Sob tal perspectiva, as estruturas são concebidas como produto da luta social e como resultado da imposição social, sendo, desse modo, analisadas diante de processos. Conforme bem observa Cardoso, "a idéia de que existe uma explicação histórico-estrutural tem a ver com o processo de formação das estruturas e, simultaneamente, com a descoberta das leis de transformação dessas estruturas. Trata-se de conceber as estruturas como relações entre os homens que, se bem são determinadas, são também [...] passíveis de mudança, à medida que, na luta privatização sejam a transferência de ativos e de capital - reelaborando as condições de concorrência, a dimensão de clientela e a política de recursos humanos da própria empresa de maneira profunda -, há especificidades na forma como o Estado busca legitimidade social para efetivar tal processo, bem como, também, quais razões levou-o a escolhê-lo (LEME, 2000).

Corroborando tal análise, Maranhão (apud ROSA, 2001, p. 13) afirma que não foi por incapacidade do Estado que o setor elétrico começou a voltar para o setor privado a partir de 1995, mas sim devido a um conjunto de pressões exógenas que cobraram, com altos juros, o pagamento da dívida feita pelo Brasil para a construção do modelo do sistema elétrico estatal e eficiente que sobreviveu até o início dos anos $1990^{16}$.

Somado a isso, Furtado (apud JORGE, 2001, p. 12) indica que o programa brasileiro de privatização - aí incluindo o setor elétrico - despontou porque a meta era resolver o balanço de pagamentos e não para solucionar a crise já anunciada por diversos especialistas, ou seja, a finalidade da privatização apresentava-se inadequada desde a sua implementação.

As empresas públicas de energia que foram privatizadas surgiram em um momento histórico em que o Brasil estava em fase de substituição das importações, precisando de indústrias e serviços que melhorassem a infra-estrutura. Isto é, o setor público surgiu como uma proposição pragmática (e menos ideológica) voltada para a promoção do desenvolvimento a partir de alavancagens produtivas e financeiramente executadas pelo Estado.

social (política, econômica cultural), novas alternativas vão se abrindo à prática histórica. Neste sentido, o objeto da análise não se reifica em atores, mas se dinamiza em conjuntos de relações sociais” (CARDOSO, 1993, p. 97; grifos no original).

16 “[...] As fissuras oriundas dos grandes investimentos em geração por meio da tomada de empréstimos internacionais de maneira inadequada à realidade financeira mundial do final dos anos [19]80. O governo tomou dinheiro spot em péssimas condições, agravando o quadro da dívida externa. [...] Além disso, alheio à crise internacional, o governo insistiu em fazer Itaipu de uma vez só, ignorando estudos dando conta de que o potencial hidroelétrico da Bacia Platina poderia ser aproveitado por várias usinas que iriam sendo construídas, com comprometimento financeiro menos oneroso” (Maranhão apud ROSA, 2001, p. 13). 
Se compararmos o processo de criação de estatais que se deu no passado e o processo de privatização que se dá no presente, podemos afirmar que o primeiro caracterizou-se como um processo determinado no espaço político nacional, enquanto o segundo caracteriza-se por um processo elitizado e impulsionado pelas forças políticas exógenas (embora pactuados com as elites locais), isto é, marcado pela disputa dos países centrais em torno dos mercados emergentes.

Embora no Brasil a sociedade civil historicamente tenha participado muito pouco dos debates em torno do planejamento do setor elétrico, com o processo de privatização isso aumentou ainda mais, excluindo a participação da sociedade civil, principalmente na esfera político-institucional. As ações do Estado estiveram, no mais das vezes, subordinadas aos conselhos de atores supranacionais e elites empresariais nacionais, isto é, não-representativos do público que potencialmente sofreria os eventuais impactos negativos da privatização. Assim, se por um lado houve a mobilização das elites junto ao aparelho estatal para dar rápida efetivação ao processo, ocorreu, por outro lado, simultânea desmobilização da sociedade civil, isto é, vendeu-se pelos meios de comunicação o processo como algo dado, sem chances de reversão e, portanto, com uma dinâmica sobre a qual a sociedade brasileira não teria poder decisório, sendo inúteis as manifestações em contrário.

Quando se verificam os processos de privatização na Inglaterra, na França e nos Estados Unidos, por exemplo, percebe-se a presença de três atores fundamentais: o Estado, o capital privado e a sociedade civil ${ }^{17}$. No Brasil, todavia, o processo tem sido marcado por dois atores e um espectador, os primeiros sendo o Estado e o capital privado (internacional ou nacional) e o espectador, a sociedade civil, caracterizada por possuir pouco peso político e pouco poder de negociação no processo.

Perante a fragilidade da participação da sociedade civil na privatização do setor elétrico brasileiro, o processo privatista tem apresentado uma

\footnotetext{
17 Alguns autores já desenvolveram vários trabalhos científicos sobre a privatização em outros países: Faria Neto (1994), Velasco Jr. (1997a; 1997b), Pires (1999) e Petras (1999).
}

legalidade jurídico-institucional e uma legitimidade social restringida ${ }^{18}$, por ser excludente.

O processo de privatização ocorrido incisivamente na década de 1990, no que concerne ao setor elétrico, ocasionou alterações significativas nos arranjos institucionais do setor e, ao mesmo tempo, redefiniu os agentes e os atores que atuam no setor. Desse modo, o setor elétrico brasileiro passou a contar com os seguintes agentes e/ou entidades para geri-lo e coordená-lo.

O Ministério das Minas e Energia (MME) é o responsável pela definição das políticas públicas do setor elétrico brasileiro e responsável pela fixação de diretrizes políticas a serem seguidas pelo setor. O MME é um órgão do poder Executivo cujos programas são elaborados com base nas diretrizes do Conselho Nacional de Política Energética. Por outro lado, ele também define as metas e os instrumentos para prestação dos serviços aos consumidores.

Entre as suas atribuições ainda consta o planejamento determinativo do sistema de transmissão e o planejamento indicativo (no qual há indícios de desrespeito) da expansão da geração, ambos executados pelo Comitê Coordenador do Planejamento da Expansão dos Sistemas Elétrico (CCPE) (ANEEL, 2001).

A Aneel incorporou as atividades reguladoras do Dnaee, que, por sua vez, sempre apresentou dificuldades de funcionamento por motivos político-econômicos. A Aneel é uma autarquia especial, vinculada ao MME; formalmente ela é um órgão do Estado, autônoma, que regula e fiscaliza as atividades do setor. Cabe à Aneel a implementação das diretrizes e das políticas energéticas do poder Executivo e genericamente lhe cabe a função de implementar políticas e de regular e fiscalizar o setor elétrico.

A Aneel ainda gerenciou dois programas inseridos no Plano Plurianual (PPA) do governo fede-

18 A "legitimidade social restringida" define-se como o processo pelo qual setores/estratos ou grupos sociais têm apoiado a reestruturação no setor, por um lado, e, por outro lado, parte significativa da sociedade civil tem realizado manifestações, protestos e reivindicações sócio-políticas - sem ser ouvida, muito menos atendida; mais do que isso, não há espaços públicos ou institucionais para que essa parcela da sociedade possa expressar suas opiniões e encaminhar suas demandas, de modo que uma parcela relevante da sociedade civil está sendo excluída do processo. 
ral do período 2000-2003: o Programa de Qualidade dos Serviços de Energia Elétrica (que visava a garantir a qualidade dos serviços prestados pelos agentes do setor) e o Programa de Abastecimento de Energia Elétrica (que procurava criar condições para o aumento da oferta de energia).

Dos cinco diretores da Aneel, três têm que ser sabatinados pelo Congresso Nacional, enquanto os outros dois são diretamente nomeados pelo Presidente da República - o que lhes daria uma considerável estabilidade nos cargos, uma autonomia e uma independência decisória. Entretanto, alguns problemas têm interferido negativamente na atuação desse órgão: 1) a inexistência de tradição regulatória de serviços públicos no Brasil e 2) a falta de pessoal qualificado para exercer essas novas funçõs, tendo em vista que a legislação veda a participação de técnicos oriundos de empresas elétricas (ROSA, TOLMASQUIM \& PIRES, 1998).

Com a recente mudança de governo na presidência da república, uma dúvida, ou pergunta se faz necessário: uma vez a Aneel movimentando um orçamento volumoso via Fundos Setoriais e tendo sua diretoria eminentemente sobre outro olhar político, como se dará a relação para implementação de políticas com este orçamento tendo aparentemente um conflito (ou a possibilidade de) entre a diretoria da Aneel e o novo governo?

Na verdade, tal conflito foi substantivamente eliminado a partir da elaboração do Novo Modelo do Setor Elétrico (julho de 2003) elaborado pelo Ministério das Minas e Energia sob o comando da Ministra Dilma Rousseff. Esse Novo Modelo estabeleceu uma nova reestruturação setorial, que, por um lado, reduziu o alcance de atuação da Aneel e, por outro lado, reintegrou a função de planejamento setorial e restaurou o papel de poder concedente ao MME.

O ONS é o responsável pelas atividades de geração e transmissão de todo o sistema eletroenergético interligado. É uma entidade de direito privado, integrada pelas empresas de geração, transmissão, distribuição e comercialização, além dos importadores e exportadores de energia e dos consumidores livres. As funções básicas do ONS referem-se ao planejamento e à programação das operações no setor; ao despacho de maneira centralizada na geração; à viabilidade da expansão do sistema de transmissão e mínimo custo e ao cálculo do preço spot.

O MAE ${ }^{19}$ é uma das inovações do processo de reestruturação do setor elétrico, cujo pressuposto básico consiste no estabelecimento da competição entre os agentes econômicos. Pode-se afirmar que é o MAE o ambiente em que ocorrem as compras e as vendas de energia elétrica entre os participantes por meio de contratos bilaterais e mercado de curto prazo (SAUER, 2002).

O MAE foi instituído em 1998, sendo integrado por empresas concessionárias de geração, distribuição e comercialização de energia elétrica. Ele ainda não está em pleno funcionamento, encontrando-se ainda em período de transição na tentativa de ampliação da competição entre os atores econômicos presentes no setor.

Em 2001, a Aneel interveio no MAE e promoveu uma série de mudanças que começaram com a extinção do Comitê Executivo (COEX) (encarregado da supervisão das atividades do MAE), substituindo-o pelo Comae (Conselho Operacional do MAE, de estrutura mais racional e encarregado pela gestão profissionalizada do mercado atacadista). Outra mudança foi a vinculação da atuação da Administradora de Serviços do MAE (Asmae) com a Aneel (ANEEL, 2001).

O Comitê Coordenador do Planejamento da Expansão (CCPE) é o órgão responsável pelo planejamento da expansão do sistema elétrico; dentro de suas atribuições essenciais destacam-se o planejamento determinativo da transmissão; o programa de indicativo de licitações; o programa de inventários e o programa de estudos de viabilidade (SAUER, 2002).

Os produtores independentes de Energia Elétrica (PI) são empresas ou consórcios autorizados pela Aneel a produzir e a vender energia no

19 A partir do governo Lula, com a criação do Novo Modelo do Setor Elétrico, o MAE deixou de existir e criou-se um outro desenho institucional com a elaboração da Câmara de Comercialização de Energia Elétrica (CCEE). Dentre suas atribuições, a CCEE incorporou as antigas funções exercidas pelo MAE e passou a atuar na administração de contratação de energia nos dois novos ambiente institucionais criados, um regulado - o Ambiente de Contratação Regulada (ACR), que protege o consumidor cativo - e outro livre - o Ambiente de Contratação Livre (ACL), que estimula a iniciativa dos consumidores livres. 
mercado "livre", sendo que os riscos são das próprias empresas. Em contrapartida possuem a garantia de livre acesso aos sistemas de transmissão e a autonomia para assinar contratos bilaterais.

Os agentes comercializadores de Energia Elétrica compreendem as empresas que, mesmo sendo proprietárias de usinas e sistemas elétricos, são autorizadas a atuar na comercialização de energia. Também podem participar como comercializadores os importadores e exportadores de energia, além dos produtores independentes.

É na figura do Consumidor Livre que consistiria a liberdade de escolha por parte do consumidor para comprar energia livremente no mercado, segundo sua preferência. Esse mercado ainda não está em implementação, deixando apenas para os consumidores com carga superior a $3 \mathrm{MW}$ a liberdade de escolher seus fornecedores. Segundo discursos do governo e da própria ANEEL, é intenção a efetivação deste processo de flexibilização no fornecimento de energia até 2005, incluindo aqui, para todos os consumidores de energia, inclusive os residenciais (ANEEL, 2001).

Por fim, encontram-se nesse novo arranjo institucional diversos atores vinculado aos debates sobre os recursos hídricos, havendo, nesse sentido, a participação nos órgãos setoriais de atores envolvidos com a hidroeletricidade por meio dos Comitês de Bacia e uma atuação ativa do MME e Aneel nas câmaras técnicas; há, também, uma articulação entre o CCPE, a Aneel e a Agência Nacional da Água (ANA) nos estudos de inventário de bacias; por fim, há uma definição de critérios gerais para a elaboração de Plano Diretor para os reservatórios -Conselho Nacional de Recursos Hídricos (CNRH).

Com isso fica evidente que a reflexão e a implementação de políticas no concernente à reestruturação do setor elétrico brasileiro passa necessariamente pela compreensão e pela possibilidade histórica de interpretar e explicar o conjunto de relações em que o setor encontra-se envolvido, relacionando com a sustentabilidade que envolve de maneira sinérgica a energia, a equidade social, o meio ambiente, o emprego e a democracia. Só assim se poderá realizar uma reestruturação, prevendo evitar as grandes disparidades que têm ocorrido tanto nas benesses geradas quanto nos prejuízos assumidos entre os diversos atores sociais, donde os mais desfavorecidos historicamente são os que mais tem sofrido os malefícios.

O embate entre o Estado e a sociedade civil organizada, no que tange à reestruturação do setor elétrico do país, apresenta muitos aspectos peculiares, de que destacaremos apenas dois. $\mathrm{O}$ primeiro refere-se ao repasse do compromisso de produção e distribuição de um serviço que se tornou cultural e socialmente essencial aos cidadãos, para agentes privados. Os últimos, por sua vez, tendem a restringir-se a uma relação meramente econômica e exclusiva, envolvendo-se em uma relação imediata com o consumidor - e não com o cidadão.

O segundo, por sua vez, sinaliza a relação estabelecida entre os grupos privados investidores em geração elétrica (seja por novas usinas hidroelétricas, seja por usinas térmicas a gás que utilizam água no processo de resfriamento) com os demais usuários dos recursos hídricos.

Ao examinarmos os loci das formas institucionais pretensamente democratizantes como os comitês de bacias hidrográficas (CBHs) - órgãos atualmente sob forte influência das prefeituras, ou seja, dos poderes locais constituídos - e o CNRH, apenas para ficar em duas das instâncias do Sistema Integrado de Gestão dos Recursos Hídricos (SIGRH) -, o que se percebe é que elas tendem a ser verticalizadas e, portanto, deterioram o afã de eqüidade que o sistema propunha-se a efetivar.

Pôde-se perceber isso, na crise de produção de energia de 1999, em que esse empresariado pressionou fortemente o Estado para que em regiões em que houvesse escassez de água para geração de energia fosse considerada prioritária a tarefa de reserva a água para esse fim, deixando os demais usos a jusante ${ }^{20}$, sejam econômicos (para culturas irrigadas e manutenção da navegabilidade, por exemplo), sejam ecológicos (para manutenção de um mínimo de integridade ecológica que não comprometa, por exemplo, o ciclo da piracema, a desova dos peixes migradores

\footnotetext{
20 Embora hoje em dia ainda não se saiba ao certo qual é a condição efetiva, quantitativa ou qualitativa, dos rios no Brasil ou mesmo no estado de São Paulo, há fortes tentativas de instituição da cobrança pelo uso de água como forma coercitiva sobre os diversos atores usuários desse recurso.
} 
que necessitam de água para completar sua viagem de subida dos rios), subordinados ao primeiro.

Nesse sentido, a emblemática reestruturação do setor elétrico brasileiro traz muito mais do que uma mera inversão de atores no comando de alguns serviços públicos essenciais, particularmente a energia elétrica. Ela dá-nos o indicativo de que também está em jogo quais os tipos de sociedade, de desenvolvimento econômico e social e de arranjos democráticos realmente queremos efetivar no país.

\section{CONSIDERAÇÕES FINAIS}

De modo geral, a reestruturação do setor elétrico brasileiro apresentou uma dinâmica políticoeconômica e institucional marcada por influências de fatores exógenos e endógenos. Dos primeiros, salientamos as proposições neoliberais (de muitos impactos deletérios à sociedade brasileiro e ao setor elétrico em particular) contidas no Consenso de Washington, proposta pelo Fundo Monetário Internacional (FMI) e pelo Banco Mundial, que, direta e indiretamente, recomendaram e/ ou indicaram metas a serem seguidas e praticadas pelos países em desenvolvimento. Essas metas em grande parte foram incorporadas e executadas pelo governo brasileiro e de que uma de suas conseqüências foi a crise e o racionamento no setor elétrico.

O neoliberalismo, enquanto proposição e prática político-econômica, tomou para si a responsabilidade de sugerir uma reformulação das funções do Estado, resgatando as idéias de Estado mínimo e livre mercado, percebendo o mercado como o espaço da produção e da reprodução do capital sem a interferência política do Estado, ou seja, como espaço de neutralidade, extra-político por excelência.

A globalização, por sua vez, ajudou a veiculação desses preceitos neoliberais. Não que a globalização deva ser encarada como uma entidade quase autônoma e independente, mas, sim, vista como um processo histórico de produção e reprodução do capital de maneira combinada e desigual que ao mesmo tempo em que visa a integrar, também salienta as diferenças, sejam elas, culturais, sociais, políticas e espirituais entre os países dos hemisférios Norte e Sul.

A globalização, vista como um processo determinado historicamente, não deve ser encarada como definitiva e muito menos como um fenômeno plenamente constituído. Por outro lado, pode-se afirmar que, por meio dela, muitas evidências foram levantadas para que as lideranças políticas no Brasil pactuassem com os atores e grupos hegemônicos da sociedade brasileira, a fim de incorporar as reformas por ela veiculada - dentre elas, a privatização dos setores de infra-estrutura, particularmente o setor elétrico.

Cabe salientar que o setor elétrico brasileiro apresentou uma vocação pela hidroeletricidade, motivada pela grande quantidade de águas interiores que o Brasil possui, chegando a aproximadamente $12 \%$ do percentual mundial.

Outra característica marcante do setor elétrico brasileiro foi que sua constituição assentou-se eminentemente sobre execução estatal (federal ou estadual), principalmente no período posterior à II Guerra Mundial, em que definitivamente ocorreu um processo de industrialização e urbanização do Brasil. O momento de maior incidência da intervenção estatal para a criação do setor elétrico (geração, distribuição e transmissão) foi durante os governos militares, de meados da década de 1960 até praticamente a metade da década de 1970.

A geração e a distribuição de energia tiveram maior ênfase, ficando a transmissão com uma base de investimentos proporcionalmente menores, ocorrendo maior dificuldade para a tão esperada integração entre o Norte e o Sul-Sudeste do país, para o aproveitamento das diferenças climáticas e pluviométricas do país.

A partir da crise do petróleo, em meados da década de 1970, algumas dificuldades do Estado e das empresas de energia elétrica em buscar financiamentos fora do país, fez que os investimentos no setor não fossem realizados na intensidade em que deveriam. Para tal fato, ainda contamos com a construção da usina hidroelétrica de Itaipu, que ocasionou um endividamento em função da forma como foi feita. Mesmo tendo estudos sobre a melhor utilização da bacia com a construção de várias usinas e durante um espaço temporal maior, o Estado brasileiro optou por construir uma única usina e de uma só vez.

O modelo estatal durou ainda toda a década de 1980 apesar da crise econômica por que o país passou; todavia, logo no começo da década de 1990, muitas reformas começaram a ser propostas e executadas, dentre elas, a privatização e 
desestatização de setores de infra-estrutura antes considerados fundamentais de serem construídos e geridos pelo Estado. Foi nesse bojo que a reestruturação do setor elétrico brasileiro iniciouse.

Um dos pressupostos essenciais da reestruturação do setor foram as privatizações das empresas de geração e distribuição de energia. As privatizações na distribuição foram mais longe, sendo privatizados nacionalmente praticamente $80 \%$ das distribuidoras na década de 1990, ao passo que as geradoras tiveram apenas cerca de $20 \%$ das empresas privatizadas. O estado de São Paulo guarda suas especificidades nesse processo, primeiramente porque efetivou a privatização em quase toda a rede de geração, restando apenas a Companhia Energética de São Paulo (CESP), que só não foi privatizada porque também apresentou problemas no processo licitatório e logo depois devido à crise do setor elétrico por que passou praticamente todo o Brasil em 2001.

Decorrente da reestruturação do setor elétrico brasileiro e da crise de 2001, pode-se afirmar que houve alguns impactos (na tarifa e em alguns casos também no acesso) para os consumidores residenciais, principalmente os de baixa renda.

Além dos diversos constrangimentos tarifários e de acesso à energia elétrica por camadas específicas de consumidores, a reestruturação do setor ainda acabou por ocasionar uma deturpação e/ ou mudança de foco da cidadania para o consu- midor; não se tratou conceitualmente, ao menos na prática considerou-se o cidadão como sendo igual ao consumidor. Com isso, reduziu-se a cidadania ao direito de consumir (direitos e deveres de quem tem renda para consumir), esquecendo, ou não levando em consideração, que a cidadania excede os direitos dos consumidores, sendo esses últimos apenas um aspecto (importante, mas não único) da cidadania, mas nunca sua totalidade.

Com isso, os conflitos e as possíveis relações a serem estabelecidas ficam reduzidas à esfera econômica dos direitos de quem tem renda para consumir. Mais do que isso, configuraram-se em uma relação social em que o principal fator é o consumo, deixando para segundo plano outras esferas importantes a serem garantidas e mantidas ou, quando muito, até entrando em conflito com elas.

Por fim, reforçamos a contradição existente entre o que o governo veiculava discursivamente como propostas, planos e planejamentos e a forma como realmente os implementa. Nesse sentido, o setor elétrico é bastante ilustrativo, seja devido à deflagração da crise e do próprio racionamento no setor, seja devido à forma como seus interlocutores oficiais justificaram tanto um quanto outro. Acreditamos que a superação dessa contradição trará como marco a mudança da prática política com pouco planejamento e reativa para uma forma pró-ativa, com maior inclusão social e um melhor planejamento econômico e ambiental.

Alessandro André Leme (lemeaa@unicamp.br) é Doutorando em Ciências Sociais na Universidade Estadual de Campinas (Unicamp) e bolsista-docente no Departamento de Ciência Política da mesma instituição.

\section{REFERÊNCIAS BIBLIOGRÁFICAS}

ABRUCIO, F. L. \& COSTA, V. M. F. 1999. Reforma do Estado e o contexto federativo brasileiro. São Paulo : Fundação Konrad Adenauer-Stiftung.

ALMEIDA, M. H. T. 1997. A reforma negociada : o Congresso e a política de privatização. Revista Brasileira de Ciências Sociais, São Paulo, v. 12, n. 34, p. 119-132.

1999. Negociando a reforma : a privatização de empresas públicas no Brasil. Traba- lho apresentado no XXII Encontro Anual da Associação Nacional de Pós-graduação e Pesquisa em Ciências Sociais, realizado em outubro, em Caxambu (MG). Digit.

ANEEL. 2001. AANEEL na reestruturação do setor elétrico brasileiro. Brasília : Agência Nacional de Energia Elétrica.

AYERBE, L. F. 1998. Neoliberalismo e política externa na América Latina. São Pau-lo : UNESP. 
BATISTA, P. N. 1994. O Consenso de Washington : a visão neoliberal dos problemas latinoamericanos. In : LIMA SOBRINHO, A. J. B. (org.). Em defesa do interesse nacional. Rio de Janeiro : Paz e Terra.

BERMANN, C. 2002. Energia no Brasil : para quê? Para quem? Crise e alternativas para um país sustentável. São Paulo : Livraria da Física.

BIONDI, A. 1999. O Brasil privatizado : um balanço do desmonte do Estado. São Paulo : Fundação Perseu Abramo.

2000. O Brasil privatizado II : o assalto das privatizações continua. São Paulo : Fundação Perseu Abramo.

BNDES. 1997. Programa Nacional de Desestatização. Relatório de atividades. Rio de Janeiro : Banco Nacional de Desenvolvimento Econômico e Social. Disponível em : http:// www.bndes.gov.br. Acesso em : 01.jan.2003.

BORON, A. 1994. Estado, capitalismo e democracia na América Latina. São Paulo : Paz e Terra.

BRESSER-PEREIRA, L. C. 1998. Economia brasileira : uma introdução crítica. $3^{\mathrm{a}}$ ed. São Paulo. ed. 34.

BRESSER-PEREIRA, L. C.; WILHEIM, J. \& SOLA, L. 1999. Sociedade e Estado em transformação. São Paulo : UNESP.

BRUNHOFF, S. 1991. A hora do mercado : crítica do liberalismo. São Paulo : UNESP.

CALABI, A. S. (org.). 1983. A energia e a economia brasileira. São Paulo : Pioneira.

CANO, W. 1988. A interiorização do desenvolvimento econômico no interior paulista. Col. "Economia paulista”, v. 1. São Paulo : Fundação Sistema Estadual de Análise de Dados.

1995. Reflexões sobre o Brasil e a no-va (des)ordem internacional. $4^{\text {a }}$ ed. Campinas : UNICAMP.

2000. Soberania e política econômica na América Latina. São Paulo : UNESP.

CARDOSO, F. H. 1993. As idéias e seu lugar. Petrópolis : Vozes.

CARDOSO, F. H. \& FALETO, E. 1970. Dependência e desenvolvimento na América Latina. $7^{\text {a }}$ ed. Rio de Janeiro : Livros Técnicos e Científicos.

CASANOVA, P. G. 1997. Globalidade, neoliberalismo e democracia. In : FERREIRA, L. C. (org.). A sociologia no horizonte do século XXI. São Paulo : Boitempo.

CASTELLS, M. 1999. A sociedade em rede. São Paulo : Paz e Terra.

CEPAL. 2002. Globalización y desarrollo. Santiago de Chile : Comisión Económica para América Latina y el Caribe.

DINIZ, E. 1997. Crise, reforma do Estado e governabilidade. Rio de Janeiro : Fundação Getúlio Vragas.

DONAHUE, J. D. 1992. Privatização. Fins públicos, meios privados. Rio de Janeiro : J. Zahar.

DOWBOR, L. 1995. Da globalização ao poder local. Anova hierarquia dos espaços. São Paulo em Perspectiva, v. 9, n. 3. jul.-set.

2000a. Capitalismo : novas dinâmicas, outros conceitos. Disponível em : http:// www.ppbr.com/ld/. Acesso em : 19.jun.2006.

2000b. Neoliberalismo brasileiro e seus mentores. Disponível em : http:// www.ppbr.com/ld/. Acesso em : 19.jun.2006.

EASTERLY, W. \& SERVÉN, L. 2003. The Limits of Stabilization : Infrastructure, Public Deficits, and Growth in Latin America. Stanford : Stanford University.

EDWARDS, S. 1995. Crisis and Reform in Latin America : From Despair to Hope. Oxford : Oxford University.

ELETROPAULO. 1997. Estatização x privatização. História \& Energia, n. 7. São Paulo : Companhia Paulista de Eletricidade.

FARIA NETO, P. S. 1994. Gestão efetiva e privatização : uma perspectiva brasileira. Rio de Janeiro : Qualitymark.

FAUSTO, B. 2001. História concisa do Brasil. São Paulo : USP.

FERNANDES, F. 1981. Capitalismo dependente e classes sociais na América Latina. Rio de Janeiro. Zahar.

FERREIRA, C. K. L. 2000. Privatização do setor elétrico no Brasil. In : PINHEIRO, A. C. \& 
FUKASAKU, K. (orgs.). A privatização no Brasil. O caso dos serviços de utilidade pública. Rio de Janeiro : Banco Nacional de Desenvolvimento Econômico e Social.

FIORI, J. L. 1995. Em busca do dissenso perdido : ensaios críticos sobre a festejada crise do Estado. Rio de Janeiro : Insight.

FRIEDMAN, M. 1984. Capitalismo e liberdade. Col. "Os economistas”. São Paulo : Abril Cultural.

FURTADO, C. 1992. Brasil, a construção interrompida. Rio de Janeiro : Paz e Terra.

GIDDENS, A. 1991. As conseqüências da modernidade. São Paulo : UNESP.

2000. Mundo em descontrole : o que a globalização está fazendo de nós. Rio de Janeiro : Record.

HUNT, E. K. \& SHERMAN, H. J. 1977. História do pensamento econômico. Petrópo-lis : Vozes.

IANNI, O. 1986. Estado e planejamento econômico no Brasil. Rio de Janeiro : Civilização Brasileira.

1995. Teoria da globalização. $2^{\text {a }}$ ed. Rio de Janeiro : Civilização Brasileira.

1997. A era do globalismo. $3^{\text {a }}$ ed. Rio de Janeiro : Civilização Brasileira.

JANNUZZI, G. M. 1996. A política energética e o meio ambiente : instrumentos de mercado e regulação. In : ROMEIRO, A. R.; RYDON, B. P. \& LEONERDI, M. L. A. (orgs.). Economia do meio ambiente : teoria, políticas e gestão de espaços regionais. Campinas : UNICAMP.

JORGE, W. 2001. Tragédia encenada por amadores. Jornal da Unicamp, Campinas, ano XV, n. 164, p. 12, jul. Edição especial sobre a crise energética.

LEITE, A. D. 1995. A energia do Brasil. Rio de Janeiro : Nova Fronteira.

LEME, A. A. 2000. O impacto da privatiza-ção da CESP sobre o processo de implantação de uma nova obra da concessionária : uma abordagem sociológica acerca do caso de Santa Maria da Serra (SP). São Carlos. Monografia (Graduação em Ciências Sociais). Universidade Federal de São Carlos.
2001. A reestruturação do setor elétrico brasileiro : privatização e crise em perspectiva. In : FELICIDADE, N.; MARTINS, R. C. \& LEME, A. A. (orgs.). Uso e gestão dos recursos hídricos no Brasil. São Car-los : RiMa.

2003. A reestruturação do setor elétrico brasileiro : uma abordagem sociológica acerca da privatização. São Carlos. Dissertação (Mestrado em Ciências Sociais). Universidade Federal de São Carlos.

LESSA, C. 1983.15 anos de política econômica. São Paulo : Brasiliense.

LONGO, R. \& BREMANN, C. 2002. Avaliação do processo de reestruturação do setor elétrico brasileiro : das propostas à realidade. Anais do IX Congresso Brasileiro de Energia-IV Seminário Latino-Americano de Energia, realizado de 20 a 22 de maio. Rio de Janeiro : CDROM.

MACIEL, C. S. 1997. Globalização, crise do padrão de financiamento da economia $e$ reestruturação institucional do setor elétrico brasileiro. Campinas. Tese (Doutorado em Economia). Universidade Estadual de Campinas.

MANTEGA, G. 1986. A Economia Política brasileira. São Paulo : Brasiliense.

MARQUES, M. 2000. Privatização prejudicou mais consumidor de baixa renda. Gazeta Mercantil, São Paulo, 22.fev.

MARTIN, J. M. 1992. A economia mundial da energia. São Paulo : UNESP.

MEDEIROS, R. 1996. O capital privado na reestruturação do setor elétrico brasileiro. História \& Energia, n. 6. São Paulo : Companhia Paulista de Eletricidade.

MEIRELES, S. 1999. Setor elétrico em choque. Cadernos do Terceiro Mundo, Rio de Janeiro, n. 212, set.

MELLO, M. F. 1992. A privatização no Brasil : análise dos seus fundamentos e experiências internacionais. São Paulo. Tese (Doutorado em Economia). Universidade de São Paulo.

MIELNIK, O. \& NEVES, C. C. 1988. Características da estrutura de produção de energia hidroelétrica no Brasil. In : ROSA, L. P.; SIGAUD, L. \& MIELNIK, O. (orgs.). Impac- 
tos de grandes projetos hidrelétricos e nucleares. São Paulo : Marco Zero.

NUNES, E. 2001. O quarto poder : gênese, contexto, perspectivas e controle das agências reguladoras. Artigo apresentado no II Seminário Internacional sobre Agências Reguladoras de Serviços Públicos, realizado em Brasília, em 25 de setembro. Digit.

OLIVEIRA, F. 1998. Os direitos do antivalor : a economia política da hegemonia imperfeita. Petrópolis : Vozes.

PASSET, R. 2002. A ilusão neoliberal. Rio de Janeiro : Record.

PAUNOVIC, I. 2000. Growth and Reforms in Latin America and the Caribbean in the 1990s. Série "Reformas econômicas", n. 70. Santiago de Chile : Comisión Económica para América Latina y el Caribe. Disponível em : http:// www.eclac.cl/. Acesso em : 10.jan.2006.

PETRAS, J. 1999. Armadilha neoliberal e alternativas para a América Latina. São Paulo : Xamã.

PIRES, J. C. L. 1999. Políticas regulatórias no setor de energia elétrica : a experiência dos Estados Unidos e da União Européia. Rio de Janeiro : Banco Nacional de Desenvolvimento Econômico e Social.

REZENDE, F. \& PAULA, T. B. (coords.). 1997. Infra-estrutura: perspectiva de reorganização. Setor Elétrico. Rio de Janeiro : Instituto de Pesquisas Econômicas Aplicadas.

ROSA, J. M. 2001. Os apagões dos “anos dourados”. Jornal da Unicamp, Campinas, ano XV, n. 164, p. 13, jul. Edição especial sobre a crise energética.

ROSA, L. P. 2002. A crise de energia elétrica : causas e medidas de mitigação. In : BRANCO, A. M. (org.). Política energética e crise de desenvolvimento. São Paulo : Paz e Terra.

ROSA, L. P.; TOLMASQUIM, M. T. \& PIRES, J. C. L. 1998. A reforma do setor elétrico no Brasil e no mundo : uma visão crítica. Rio de Janeiro : Relume-Dumará.

ROSANVALLON, P. 2002. O liberalismo econômico : história da idéia de mercado. Bauru : USC.
SALLUM JÚNIOR, B. 2003. Metamorfoses do Estado brasileiro no final do século XX. Revista Brasileira de Ciências Sociais, São Paulo, v. 18, n. 52, p. 35-55.

SANTOS, B. S. 1997. Pela mão de Alice : o social e o político na pós-modernidade. São Paulo : Cortez.

SANTOS, M. 1998. Técnica, espaço, tempo. São Paulo : Hucitec.

SANTOS, W. G. 1978. Ordem burguesa e liberalismo político. São Paulo : Duas Cidades.

SAUER, I. 2002. Energia elétrica no Brasil contemporâneo : a reestruturação do setor, questões e alternativas. In : BRANCO, A. M. (org.). Política energética e crise de desenvolvimento. São Paulo : Paz e Terra.

SOUZA, J. 2000. A modernização seletiva : uma reinterpretação do dilema brasileiro. Brasília : UNB.

SOUZA JÚNIOR, J. A. 1996. Globalização, indústria de eletricidade e desenvolvimento sustentável. In : ROMEIRO, A. R.; RYDON, B. P. \& LEONERDI, M. L. A. (orgs.). Economia do meio ambiente : teoria, políticas e gestão de espaços regionais. Campinas : UNICAMP

TAVARES, M. C. 1972. Da substituição de importações ao capitalismo financeiro. Rio de Janeiro : Zahar.

TAVARES, M. C. \& ASSIS, J. C. 1986. Um grande salto para o caos. $2^{\mathrm{a}}$ ed. Rio de Janeiro : J. Zahar.

TAVARES, M. C. \& FIORI, J. L. 1993. Desajuste global e modernização conservadora. São Paulo : Paz e Terra.

TAVARES, M. C. \& MELIN, L. E. 1998. Mitos globais e fatos regionais : a nova desordem internacional. In : FIORI, J. L.; LOURENÇO, M. S. \& NORONHA, J. C. (orgs.). Globalização. O fato e o mito. Rio de Janeiro : UERJ.

TOLMASQUIM, M. T. \& CAMPOS, A. F. 2002. A reforma do setor elétrico em perspectiva. Anais do IX Congresso Brasileiro de EnergiaIV Seminário Latino-Americano de Energia, realizado de 20 a 22 de maio. Rio de Janeiro : CD-ROM. 
VELASCO E CRUZ, S. C. 1998. Argumentos sobre reformas para o mercado nos países em desenvolvimento. Lua Nova, São Paulo, n. 45, p. 5-27.

VELASCO JR., L. 1997a. A economia das política públicas : fatores que favoreceram as privatizações no período 1985-1994. Rio de
Janeiro : Banco Nacional de Desenvolvimento Econômico e Social.

1997b. A economia política das políticas públicas : as privatizações e a reforma do Estado. Rio de Janeiro : Banco Nacional de Desenvolvimento Econômico e Social.

\section{OUTRAS FONTES}

BRASIL. 1988. Constituição da República Federativa do Brasil. Brasília : Congresso Nacional. Disponível em : https:// www.planalto.gov.br/ccivil_03/Constituicao/ Constitui\%E7ao.htm. Acesso : 19.jun.2006.
H2OPLANET. 2006. Economia. Disponível em : http://members.fortunecity.com/guilhermerp/. Acesso em : 19.jun.2006.

Revista Memória Eletropaulo. 1997. São Paulo, n. 24. 